\title{
Efektifitas Penilaian Prestasi Kerja Pegawai Terhadap Promosi Jabatan Pada Badan Kepegawaian Dan Pendidikan Pelatihan Daerah Kabupaten Buton
}

\author{
Arfina \\ Pegawai Negeri Pemerintah Kabupaten Buton \\ Email: arfina.fina@gmail.com
}

\begin{abstract}
Abstrak, Tujuan Penelitian ini adalah untuk mengkaji hasil penilaian kinerja yang dilakukan oleh Badan Kepegawaian dan Pendidikan Pelatihan Daerah Kabupaten Buton, terhadap Promosi Jabatan yang dilakukan. Penelitian ini adalah Penelitian Kualitatif, dimana data diperoleh melalui serangkaian wawancara mendalam dan telaah terhadap dokumentasi yang ada dan relevan. Dari hasil penelitian, dapat dijelaskan bahwa efektifitas penilaian prestasi kerja didasarkan pada kegiatan yang telah dilaksanakan seperti pemantauan, pelaksanaan kehadiran/disiplin, pertangungjawaban dalam pembuatan laporan hasil kerja, kehadiran dalam rapat kerja, pemeriksaan dan pengawasan, kesemuanya iu merupakan sal satu produk keberhasilan pegawai dalam penilaian dan peningkatan prestasi kerja bagi aparatur. Sedangkan, Faktor-faktor yang mempengaruhi promosi jabatan mempunyai pengaruh terhadap Pengembangan Karir Pegawai dengan Implikasinya pegawai di lingkungan Badan Kepegawaian Daerah dan Diklat Kabupaten Buton, dikarenakan adanya mutasi yang mengharuskan pegawai untuk ke luar daerah. Namun demikian masih terdapat hubungan positif dan dapat dipercaya antara promosi jabatan terhadap pengembangan karir pegawai di lingkungan Badan Kepegawaian dan Diklat Daerah Kabupaten Buton.
\end{abstract}

Kata Kunci: Efektivitas, Prestasi Kerja, Promosi, Buton 


\section{Pendahuluan}

Promosi jabatan merupakan sarana yang dapat mendorong pegawai untuk lebih baik atau lebih bersemangat melakukan suatu pekerjaan dalam lingkungan organisasi. Dengan melihat fakta tersebut maka penilaian kerja yang mengarah pada promosi jabatan harus dilakukan dengan efektif agar dapat diterima semua pihak tanpa ada yang merasa dirugikan. Penilaian kinerja dan promosi jabatan sangat erat kaitanya dan juga menjadi hal sensitif dalam pemerintahan. Hal ini sesuai dengan substansi UU Nomor 5 Tahun 2014 tentang Aparatur Sipil Negara (ASN) adalah berkenaan dengan Pangkat dan Jabatan., Pengembangan Karier, Pola Karier dan Promosi. Pembahasan terhadap keempat materi tersebut disusun secara berurutan yakni pasal 68, 69, 70 dan 71 UU Aparatur Sipil Negara berisi tentang pangkat dan jabatan (pasal 69), pengembangan karier (Pasal 69) dan pola karir, promosi (pasal 71).

Dalam Undang Undang Nomor 23 Tahun 2014 tentang Pemerintahan Daerah sudah diatur mengenai wewenang kepala daerah untuk menentukan struktur Organisasi Pemerintahan Daerah dan pengisian jabatannya. Undang Undang Nomor 43 Tahun 1999 Tentang Perubahan Atas Undang Undang Nomor 8 Tahun 1974 Tentang Pokok Pokok Kepegawaian juga sudah mengatur tentang persyaratan pengisian jabatan bagi Pegawai Negeri Sipil (PNS). Pada pasal 17 ayat 2 disebutkan bahwa Pengangkatan PNS dalam suatu jabatan dilaksanakan. berdasarkan prinsip profesionalisme sesuai dengan kompetensi, prestasi kerja, dan jenjang pangkat yang ditetapkan untuk jabatan itu serta syarat obyektif lainnya tanpa membedakan jenis kelamin, suku, agama, ras atau golongan.

Untuk menjamin terpilihnya orang-orang yang profesional dan kompeten sesuai dengan standar kompetensi jabatan, maka diperlukan mekanisme seleksi dan promosi terbuka. Sebetulnya konsep promosi jabatan atau kata lainya lelang jabatan tidak jauh berbeda dengan fit and proper test, namun ada pula persepsi sementara orang yang memandang bahwa promosi jabatan atau lelang jabatan sama seperti lelang atau tender dalam proses pengadaan barang dan jasa pemerintah. Praktek ini dalam pandangan masyarakat sarat dengan makna negative yaitu praktek suap menyuap untuk mendapatkan proyek. 
Padahal sejatinya lelang jabatan justru bisa memperkecil potensi KKN karena dilakukan secara transparan, menggunakan indikator tertentu dan dilakukan oleh Panitia Seleksi dan Assesor yang dibentuk secara khusus. Sejalan dengan hal tersebut diatas, Kementerian Pemberdayaan Aparatur Negara dan Reformasi Birokrasi (Kemenpan RB) telah meluncurkan program Grand Design Reformasi Birokrasi yang dipertajam dengan rencana aksi 9 (Sembilan) Program Percepatan Reformasi Birokrasi dan salah satu diantaranya adalah Program Sistem Promosi jabatan ASN secara terbuka. Program ini bertujuan untuk menjamin tersedianya para pejabat struktural yang memiliki kompetensi jabatan sesuai kompetensi dan persyaratan yang diperlukan oleh jabatan tersebut. Untuk mencapai hal ini,perlu diadakan promosi jabatan structural berdasarkan sistem merit dan terbuka, dengan mempertimbangkan kesinambungan karier PNS yang bersangkutan.

Program reformasi birokrasi ini kemudian diperkuat dengan ditetapkannya Peraturan Menteri Pendayagunaan Aparatur Negara Dan Reformasi Birokrasi (PAN dan RB) Nomor 13 Tahun 2014 Tentang Tata Cara Pengisian Jabatan Pimpinan Tinggi Secara Terbuka Di Lingkungan Instansi Pemerintah. Dan dalam Undang Undang Nomor: 5 Tahun 2014 Tentang Aparatur Sipil Negara mengamanatkan pola manajemen karir dilaksanakan dengan promosi dan Seleksi terbuka. Promosi dan seleksi ini dilakukan untuk menempatkan PNS dalam jabatan pemerintahan (Jabatan Pimpinan Tinggi dan Jabatan Administrasi) yang memiliki kualifikasi, kompetensi, dan integritas yang baik.

Selama ini promosi jabatan dilakukan dengan mekanisme Badan Pertimbangan Jabatan dan Kepangkatan (Baperjakat) secara tertutup yang pada kenyataannya kurang berhasil memposisikan pejabat ASN dengan kualifikasi dan kompetensi yang sesuai dengan standar kompetensi jabatannya. penelitian ini difokuskan pada berbagai problematika dalam penerapan kebijakan promosi dan seleksi terbuka dengan maksud apabila mekanisme promosi dan seleksi terbuka dilakukan secara konsisten dan menghindari kepentingan tertentu maka akan terpilihlah pejabat yang memiliki kapasitas yang memadai dalam pelayanan masyarakat. Sebaliknya bila tidak diterapkan secara konsisten maka kebijakan ini hanya akan memperpanjang prosedur birokrasi dan tidak berpengaruh bagi perbaikan kinerja pemerintahan. 
Tetapi disi lain promosi jabatan merupakan kesempatan untuk berkembang dan maju yang dapat mendorong pegawai untuk lebih baik atau lebih bersemangat dalam melakukan suatu pekerjaan dalam lingkungan organisasi atau organisasi pemerintahan. Adanya target promosi jabatan, merupakan suatu tujuan bahwa pegawai dihormati karena konsistensinya kemampuan kepada pekerjaanya maupun ketaatan kepada pimpinan sesuai dengan tugas dan fungsinya sebagai pegawai negeri sipil. Jika pimpinan telah menyadari dan mempertimbangkan, maka organisasi pemerintahan akan terhindar dari masalahmasalah yang menghambat peningkatan keluaran dan dapat merugikan organisasi pemerintahan seperti: ketidakpuasan pegawai, Adanya keluhan, tidak adanya semangat kerja, menurunnya disiplin kerja, tingkat absensi yang tinggi atau bahkan masalah-masalah kemalasan kerja.

Pengamatan penulis di Pemerintahan Kabupaten Buton Khusunya di Badan Kepegawaian, Pendidikan dan Pelatihan Kabupaten Buton (BKPPM) penulis melihat dilapangan bahwa promosi jabatan sudah berlangsung lama sejak Undang-Undang dan Peraturan Menteri tentang aturan kepegawaian yang ada, tetapi di kabupaten Buton khusnya di BKPP bahwa promosi diberlakukan bagi eselon II kebawah sedangkan eselon II sudah mulai memberlakukan promosi yang sifatnya lelang jabatan ke publik. Tetapi persoalan ini semarak nanti praktek promosi terbuka ini dimulai dari Bapak Joko Widodo saat menjadi Gubernur DKI Jakarta Tahun 2013 dimulai.

Untuk itu penulis melihat aturan dan syarat-syaratnya sesuai yang ditetapkan pemerintah pusat dalam hal ini Badan Kepegawaian Negara yaitu berkenaan dengan banyaknya pertanyaan mengenai proses pengisian kepala perangkat daerah dan kepala unit kerja sebagai dampak berlakunya Peraturan Pemerintah Nomor 18 Tahun 2016 tentang Perangkat Daerah serta dengan dikeluarkannya Surat Menteri Pendayagunaan Aparatur Negara dan Reformasi Birokrasi Nomor B/3116/M.PAN/0912016 tanggal 20September 2016 yang mengatur mengenai pengisian jabatan pimpinan tinggi di lingkungan pemerintah provinsi dan pemerintah kabupaten/kota terkait dengan pelaksanaan Peraturan Pemerintah Nomor 18 Tahun 2016. 
Dari hasil tersebut, harusnya pemerintah daerah berdasarkan surat edaran Kepala Badan Kepegawaian Negara dengan No. K.26-30/V.108-6/99 pada tanggal 4 November 2016 yang telah diedarkan keseluruh pemerintah daerah mengenai organisasi pemerintahan harus mampu mengembangkan suatu perencanaan sumber daya manusia secara menyeluruh dalam menghadapi masa depan organisasi pemerintahan. Perencanaan sumber daya manusia secara menyeluruh tersebut berupa jalur-jalur karir atau promosipromosi jabatan para pegawainya. Akan tetapi tidak semua pegawai suatu organisasi pemerintahan dapat dipromosikan. Prinsip "The right man in the right place" (openempatan kerja seseorang sesuatu dengan tempatnya atau keahlianya), harus dipenuhi agar organisasi pemerintahan dapat berjalan dengan efisien dan efektif. Mengingat pentingnya pengaruh penilaian prestasi kerja ini dalam keputusan mengenai promosi pegawai, maka penulis tertarik untuk melakukan penelitian dengan judul: “Efektifitas Penilaian Prestasi Kerja Pegawai Terhadap Promosi Jabatan pada Badan Kepegawaian dan Pendidikan dan Pelatihan Daerah Kabupaten Buton.”

\section{Metode Penelitian}

Dalam penelitian ini jenis penelitian yang digunakan adalah penelitian deskripsi kualitatif, dimana penulis mengambarkan dan menjelaskan bagaimana efektifitas penilaian prestasi kerja terhadap promosi jabatan. Sampel dalam penelitian ini menggunakan terknik bentuk purpose sampling, dimana populasi dimungkinkan menjadi sampel karena jumlahnya sedikit merupakan pemilihan siapa subjek yang ada dalam posisi terbaik untuk memberikan informasi yang dibutuhkan. Dalam penarikan kesimpulan ini, didasarkan pada reduksi data dan sajian data yang merupakan jawaban atas masalah yang diangkat dalam penelitian.

\section{Pembahasan}

\section{Pelaksanaan Promosi Jabatan Pada Badan Kepegawaian Daerah Kabupaten Buton}

Fungsi pengawasan sebagai salah satu fungsi dari manajemen sangat penting dilaksanakan untuk selalu menjamin kelancaran roda pembangunan, dan efisiensi serta 
efektifitas tugas pemerintahan dapat tercapai. Pengawasan yang dilakukan oleh atasan atau pimpinan unit organisasi terhadap setiap kegiatan yang dilaksanakan oleh bawahannya merupakan upaya agar tidak terjadi penyimpangan, maka dapat segera mengambil langkah perbaikan, untuk menjamin setiap kegiatan sesuai dengan rencana yang telah ditetapkan, dalam rangka pencapaian tujuan organisasi. Selain itu, pengawasan yang dilakukan pimpinan diharapkan dapat mendorong pimpinan harus aktif dan langsung mengawasi perilaku, moral, sikap, gairah kerja dan prestasi kerja pegawai.

Dalam suatu organisasi, baik pemerintah maupun swasta, pengawasan adalah merupakan salah satu fungsi manajemen yang mutlak diperlukan. Instruksi Presiden Nomor 15 Tahun 1983 Tentang Pedoman Pelaksanaan Pengawasan menekankan pentingnya pengawasan seorang atasan/pimpinan organisasi atau satuan kerja terhadap bawahannya, di samping pengawasan fungsional oleh aparat yang terkait dan perlunya tindak lanjut hasil pengawasan yang bertanggung jawab.

Dari sejumlah wawancara yang dilakukan dapat diketahui bahwa pengawasan melekat adalah kegiatan yang dilakukan oleh setiap atasan langsung untuk mengetahui sejauh mana pelaksanaan kegiatan telah sesuai dengan yang direncanakan atau tidak. Selain itu proses pengawasan tidak semata-mata untuk mencari kesalahan, namun sebaliknya menemukan suatu kejelasan dan bagaimana upaya-upaya yang mengarah pada perbaikan. Disamping itu, penetapan standar pengawasan akan memudahkan pimpinan dalam melakukan koreksi tehadap terjadinya kesalahan-kesalahan. Pelaksanaan pengawasan melekat dapat diwujudkan melalui kegiatan pemantauan, pemeriksaan dan penilaian terhadap pelaksanaan kegiatan yang telah direncanakan.

\section{Pemantauan}

Pemantauan merupakan rangkaian tindakan mengikuti pelaksanaan suatu kegiatan serta faktor-faktor yang mempengaruhinya untuk mengetahui sedini mungkin terjadinya penyimpangan pelaksanaan pekerjaan dilihat dari kebijaksanaan maupun dari program yang telah ditetapkan. Dari hasil penelitian yang dilakukan penulis pada Staf Umum dan Kepegawaian Badan Kepegawaian dan Diklat Daerah Kabupaten Buton, 
diketahui bahwaa pemantauan dilakukan melalui laporan pertanggungjawaban baik secara tertulis maupun secara lisan. Pemantauan dilakukan oleh Kepala Badan antara lain pada saat pelaksanaan apel pagi dan apel siang, pembuatan laporan hasil kegiatan harian dan pelaksanaan rapat evaluasi kerja. Hal ini menjelaskan bahwa pengawasan pegawai dilakukan setiap saat oleh setiap pimpian di seluruh kantor di Kabupaten Buton.

\section{a. Pelaksanaan Apel Pagi dan Apel Siang}

Seluruh instansi dalam lingkup Pemerintah Daerah Kabupaten Buton termasuk Badan Kepegawaian dan Diklat Daerah Kabupaten Buton melaksanakan apel pagi dan apel siang dimaksudkan untuk meningkatkan disiplin kerja pegawai khususnya disiplin dalam penggunaan waktu, sehingga diharapkan para pegawai di Badan Kepegawaian dan Diklat Daerah Kabupaten Buton saat masuk dan pulang kantor tidak menurut kehendak pribadi tetapi sesuai dengan ketentuan yang berlaku di Badan Kepegawaian dan Diklat Daerah Kabupaten Buton.

Dengan adanya absen fingger wajah maka setiap orang yang datang pagi dan tidak terlambat dapat diketahui keaktifan masuk kantornya. Dengan demikian diharapkan agar pelaksanaan apel pagi dan apel siang dapat menemukan suatu kesadaran dalam pribadi setiap pegawai untuk mentaati segala peraturan yang telah ditetapkan sebelumnya.

Apel pagi di Badan Kepegawaian dan Diklat Daerah Kabupaten Buton dilaksanakan pada pukul 07.00 WITA yang bertempat di halaman depan kantor Bupati Kabupaten Buton, kecuali hari jum'at dilaksanakan senam pagi pada pukul 06.30 WITA yang dilanjutkan dengan kegiatan Jum'at bersih. Pada pelaksanaan apel pagi dilakukan pengecekan terhadap kehadiran pegawai tiap bagian, yang dilakukan oleh pegawai yang ditunjuk sebagai pemimpin barisan. Setelah dilakukan pengecekan kehadiran oleh pemimpin barisan, hasil pengecekan kehadiran tersebut kemudian disampaikan staf dari Bagian Kepegawaian yang bertugas mencatat tingkat kehadiran pegawai dari masingmasing bagian. Staf dari bagian kepegawaian tersebut kemudian menyampaikan hasil pengecekan tersebut kepada pegawai yang bertugas sebagai pemimpin apel.

Pada setiap apel pagi tersebut, pembina apel antara lain menyampaikan hal-hal yang perlu diperhatikan oleh segenap pegawai yang hadir. Di samping itu juga berisi ajakan 
kepada seluruh pegawai dalam melaksanakan berbagai program atau kebijaksanaan dan dapat berupa koreksi terhadap tugas-tugas yang telah dilaksanakan. Selain itu melalui apel pagi pembina apel juga menyampaikan informasi tentang tugas-tugas yang akan dihadapi nantinya.

Hal ini disebabkan adanya pegawai yang melaksanakan monitoring atau kegiatan ke luar kantor yang melebihi waktu apel siang, ada yang izin karena alasan tertentu, serta ada pula yang pulang tanpa izin prosentasenya sangat kecil. Rekapitulasi kehadiran pegawai pada Badan Kepegawaian dan Diklat Daerah Kabupaten Buton setiap hari dicek oleh masing-masing kepala unit/satuan kerja.

\section{b. Pembuatan Laporan Hasil Kegiatan Harian}

Untuk meningkatkan daya guna dan hasil guna dari pelaksanaan tugas dan fungsinya, Kepala Badan Kepegawaian dan Diklat Daerah Kabupaten Buton telah menginstruksikan kepada seluruh bidang kerja yang terdapat pada organisasi Badan Kepegawaian dan Diklat Daerah Kabupaten Buton untuk membuat laporan tentang hasil kegiatan harian. Hal ini merupakan salah satu upaya pimpinan dalam memantau kegiatan stafnya.

Untuk itu sangat diperlukan rencana kerja yang jelas dan terprogram guna menunjang efektifitas dan efisiensi waktu dalam pelaksanaan tugas. Dari hasil wawancara penulis dengan para Kepala Bidang, laporan hasil kerja biasanya diserahkan kepada Kepala Badan Kepegawaian pada siang hari menjelang apel siang atau tergantung pada selesainya pekerjaan.

Melalui laporan hasil pekerjaan ini, setiap pimpinan dapat memantau pelaksanaan tugas para stafnya apakah sudah mencapai hasil yang diharapkan atau tidak. Dalam pelaksanaannya, laporan hasil kegiatan harian biasanya dibuat secara tertulis. Akan tetapi, ada juga yang dilaporkan secara lisan tergantung instruksi dari pimpinan untuk menilai apakah laporan tersebut layak dilaporkan secara lisan atau secara tertulis. Kepala Badan Kepegawaian dan Diklat Daerah Kabupaten Buton menerapkan beberapa prinsip yang harus dipenuhi pegawai dalam pelaporan, antara lain : 
a. Laporan dibuat sesuai dengan tugas dan tanggung jawab yang diemban, dengan kata lain isi laporan harus dalam batas tugas-tugas yang menjadi tanggung jawab pelapor.

b. Permintaan laporan, baik secara perorangan maupun perbidang, harus sesuai dengan tugas yang menjadi tanggung jawabnya.

c. Laporan sederhana dan konsisten, dalam arti bahwa isi laporan harus selalu berkenaan dengan pokok masalah yang dilaporkan.

d. Laporan yang memerlukan biaya berupa pengumpulan data dan persiapan pelaporan diusahakan seekonomis mungkin.

e. Laporan tentang kemajuan atau pelaksanaan sesuatu, memuat perbandingan dengan tolok ukur tertentu, antara lain :

1. Standar biaya, standar kualitas

2. Jatah atau target anggaran yang tersedia

3. Hasil pelaksanaan pekerjaan yang sama pada masa lalu.

f. Laporan dibuat secara tepat waktu, laporan yang tepat waktu akan dapat dimanfaatkan untuk perbaikan pelaksanaan pekerjaan berikutnya. Laporan yang terlambat, tidak banyak gunanya dalam mengambil keputusan atau mengambil tindakan korektif dan perbaikan.

\section{b. Pelaksanaan Rapat Evaluasi Kerja}

Rapat evaluasi kerja merupakan media komunikasi antara pimpinan dan para staf yang ada di unit kerja tersebut. Dari hasil pengamatan yang penulis lakukan bahwa rapat evaluasi kerja dilakukan pada setiap akhir bulan atau setiap minggu keempat. Pada Badan Kepegawaian dan Diklat Daerah Kabupaten Buton, rapat dipimpin langsung oleh Kepala Badan dan diikuti oleh seluruh staf yang ada.

Dalam rapat ini dibahas tentang evaluasi pekerjaan selama satu bulan terakhir. Pimpinan akan mengoreksi setiap kegiatan-kegiatan yang tidak sesuai dengan apa yang telah ditetapkan dan akan memberikan tindakan koreksi kepada staf yang dinilai tidak konsekuen dalam melaksanakan tugas. Tindakan koreksi tersebut pada umumnya berupa teguran yang bertujuan untuk perbaikan di masa yang akan datang. 
Rapat evaluasi kerja ini merupakan sarana untuk terjalinnya komunikasi dua arah antara pimpinan dengan bawahan tentang proses pelaksanaan pekerjaan serta hambatanhambatan apa yang dihadapi dalam pelaksanaan tugas. Di samping itu, melalui pelaksanaan rapat dinas akan dapat dipantau apakah pelaksanaan tugas telah sesuai dengan rencana atau tidak.

Dari uraian tersebut di atas dapat disimpulkan bahwa pelaksanaan rapat evaluasi merupakan hal yang sangat efektif karena melalui forum tersebut setiap masalah yang terjadi akan dapat dicari penyelesaiannya tanpa mengganggu aktivitas kerja.

\section{Faktor Penghambat Pelaksanaan Pengangkatan Pegawai Negeri Sipil}

Persyaratan pengangkatan jabatan dalam jabatan struktural di lingkungan Pemerintah Kabupaten Buton menitik beratkan pada syarat-syarat mengenai pegawai yang diperlukan pada suatu jabatan untuk mencapai hasil kerja lebih baik, efektif , efisien dan Profesional. Untuk itu, harus memenuhi syarat-syarat harus dipenuhi untuk melaksanakan pengangkatan dalam jabatan struktural di lingkungan Pemerintah Kabupaten Buton. Dan berpedoman pada persyaratan yang telah diatur dalam peraturan dan disesuaikan dengan kebutuhan daerah. Dalam pelaksanaan pengangkatan Pegawai Negeri Sipil (PNS) dalam jabatan struktural yang nantinya akan ada hambatan untuk melaksanakan pengangkatan, Hambatan dalam melakukan pengangkatan dalam jabatan struktural selayaknya dihindari atau diminimalkan agar proses dari pelaksanaan pegawai bisa lebih optimal atau sesuai dengan tujuan yang dilakukannya dalam pengangkatan pegawai.

Pegawai tim yang melakukan pengangkatan yang disebut juga tim penilai kerja pegawai juga manusia, maka suatu kesalahan mungkin saja terjadi atau terdapat kendala dalam melakukan pengangkatan dalam jabatan struktural. Hambatan tersebut bisa berasal dari internal ataupun eksternal. Walaupun pemerintah pusat telah membuat aturan yang jelas dan dan rinci terhadap pelaksanaan pengangkatan dalam jabatan struktural. Namun bisa saja timbul permasalahan ataupun hambatan yang nantinya akan timbul diluar perkiraan dari tim atau badan kepegawaian pada saat dilakukannya pelaksanaan penganggakatan pegawai. Adapun hambatannya yaitu: 
1. Merekomendasikan Pegawai Negeri Sipil, Tim penilai kinerja pegawai dalam merekomendasikan Pegawai Negeri Sipil yang akan naik pangkat dalam jabatan struktural, harus benar-benar memilih orang-orang yang sudah memenuhi syaratsyarat yang sudah ada. Akan tetapi dalam kenyataannya syarat-syarat kompetensi itu sendiri belum ada. Pegawai negeri yang sudah memenuhi syarat direkomendasikan oleh dinas-dinas yang bersangkutan. Langkah awal yang dilakukan adalah perlengkapan berkas-berkas dan selanjutnya melalui tahap tes psikologis, kesehatan dan dan lain-lain. Pegawai Negeri Sipil (PNS) yang sudah melalui tahap berikut, selanjutnya merupakan tugas tim penilai kerja pegawai untuk menyeleksi siapa yang memenuhi syarat melalui rapat. Tahap akhir diserahkan kepada bupati. Pegawai Negeri Sipil (PNS) yang sudah dinyatakan lulus dalam tahap-tahap pengangkatan dalam jabatan struktural tersebut dikeluarkan SK dan selanjutnya dilantik oleh bupati.

2. Badan Kepegawaian, Pendidikan dan Pelatihan sekarang ini masih mencari calon yang akan menduduki jabatan sekretaris Daerah eselon IIa dan menggunakan sistem Open beading. Sistem open beading adalah sistem lelang terbuka. Hambatannya dalam melakukan sistem Open Beading adalah orang-orang yang mendaftar untuk menduduki jabatan struktural eselon II.a hanya 2 samapai 3 orang dan dalam hal ini mempunyai kesulitan dalam proses pemilihan mana yang telah memenuhi syarat karena daftar calon yang mendaftrkan diri hanya sedikit.

3. Syarat Administasitif, Tim Penilai kinerja Pegawai harus secara berkala dalam menyusun penilaian terhadap pegawai. Hal tersebut dapat dilakukan dengan memberikan penilaian kinerja secara tertulis, agar setiap pegawai dapat mengetahui tentang kinerjanya. Syarat administratif ini dapat berupa sertifikat kegiatan peniaian dan keperluan penilaian yang relevan terhadap pelaksanaan penilaian kinerja pegwai, terutama di lingkungan Badan Kepegawaian Daerah Kabupaten Buton. Oleh karena itu setiap pegawai dapat menjadikan penilaian kinerja sebagai acuan untuk memenuhi persyaratanjabatan struktural. Dengan demikian diperlukan 
komitmen dari setiap pegawai untuk memenuhi persyaratan-persyaratan yang diperlukan.

4. Pegawai Negeri Sipil yang minim, Sekarang ini Pegawai Negeri Sipil (PNS) di lingkungan Badan Kepegawaian, Pendidikan dan Pelatihan yang semakin minim artinya Pegawai Negeri Sipil (PNS) yang semakin sedikit. Meskipun sekarang ini belummerasakan adanya hal tersebut, begitu nantinya akan ada kelembagaan baru akan tetapi dengan banyak pejabat yang purna, dan nantinya eselon IV, stafnya hanya 1 atau 2. otomatis untuk menggantikan posisi berapa tahun kedepan tersebut sangat sulit dicari.otomatis akan memutuhkan banyak pegawai negeri sipil. Adanya moratorium pengadaan Pegawai Negeri Sipil (PNS) yang dilakukan oleh Kementrian Pendayagunaan Apartur Negara Reforfamasi dan Birokrasi dari tahun 2012 dan banyaknya pensiun pegwai negeri, mengakibatkan dampak adanya kurangnya pegawai di lingkungan pemerintahan kabupaten Buton. Dalam rangka pelaksanaan pengangkatan jabatan stuktural di lingkungan Badan Kepegawaian, Pendidikan dan Pelatihan telah sesuai dengan prosedur dan perturan perundangan yag berlaku. Namun, masih terdapat beberapa hambatan atau kendala baik internal maupun eksternal.

\section{Faktor-Faktor Yang Menghambat Sistem Penilaian Kinerja Pegawai}

Kegiatan penilaian kinerja sangat mudah tergelincir pada kekeliruan, terutama jika kurang cermat dan tidak berhati-hati dalam melaksanakannnya. Hasil penilaian kinerja yang tidak baik disebabkan oleh banyak faktor, dimana keseluruhan faktor tersebut dapat dikatakan sebagai hambatan. Menurut Veithzal Rivai (2005:120) menyatakan "Halangan lain dalam penilaian kerja secara efektif adalah perspektif berbeda-beda yang dibawa sejak semua pihak ke dalam proses"Berdasarkan data yang diperoleh dari hasil penelitian dilapangan, faktor-faktor yang menghambat pelaksanaan penilaian pegawai Badan Kepegawaian, Pendidikan dan Pelatihan Buton adalah sebagai berikut:

a. Penilaian Kurang Objektif Kendala yang banyak ditemui dalam pelaksanaan penilain kinerja adalah faktor subyektifitas penilaian penilai terhadap pegawai yang dinilai. 
Hal tersebut biasa terjadi dalam suatu penilaian, karena ada unsur-unsur manusia didalamnya.

Hal ini sesuai dengan teori Veithzal Rivai dan Ahmad Fawzi Mohd. Basri (2005:121127) yang mengatakan bahwa bentuk bias yang umumnya terjadi dalam penilaian kinerja adalah Leniency and Strictness Bias (Bias Terlalu Longgar atau Terlalu Ketat). Bias penilaian ini merupakan akibat dari adanya keinginan penilai untuk tidak mempersulit atau memberikan kemudahan kepada individu yang akan dievaluasi.

b. Kurang adanya komunikasi

Kurang adanya komunikasi antara penilai dengan pegawai yang dinilai, hal itu mengakibatkan kurangnya informasi akan aspek-aspek pelaksanaan penilaian kinerja. Menurut Robbin, S. P (1991:26) mengatakan “Kekuatan yang paling menghambat keberhasilan pencapaian kinerja kelompok adalah kurangnya komunikasi yang efektif.

\section{Kesimpulan}

Mencermati pembahasan diatas, kesimpulan dari penelitian ini adalah Efektifitas penilaian prestasi kerja didasarkan pada kegiatan yang telah dilaksanakan seperti pemantauan, pelaksanaan kehadiran/disiplin, pertangungjawaban dalam pembuatan laporan hasil kerja, kehadiran dalam rapat kerja, pemeriksaan dan pengawasan, kesemuanya iu merupakan sal satu produk keberhasilan pegawai dalam penilaian dan peningkatan prestasi kerja bagi aparatur. Sedangkan, Faktor-faktor yang mempengaruhi promosi jabatan mempunyai pengaruh terhadap Pengembangan Karir Pegawai dengan Implikasinya pegawai di lingkungan Badan Kepegawaian Daerah dan Diklat Kabupaten Buton, dikarenakan adanya mutasi yang mengharuskan pegawai untuk ke luar daerah. Namun demikian masih terdapat hubungan positif dan dapat dipercaya antara promosi jabatan terhadap pengembangan karir pegawai di lingkungan Badan Kepegawaian dan Diklat Daerah Kabupaten Buton. 


\section{Daftar Pustaka}

Abdulrahmat, 2003, Efektifitas Pemanfaatan Sumber Daya, Sarana Dan Prasarana Kerja, Bumi Persada Bandung

Arikunto, Suharsimin. 2002. Prosedur Penelitian suatu pendekatan Praktek, Rineka Cipta Jakarta.

Cahayani, Ati. Strategi Dan Kebijaksanaan Manajemen Sumber Daya Manusia. PT Indeks, Jakarta.

Dajan, Anton. 1983 Pengantar Metode Statistik, LP3ES. Jakarta

Dessler, Gary. 1996, Manajemen Sumber Daya Manusia, Edisi Kesembilan: PT Indeks Kelompok Gramedia, Jakarta

Hasibuan, Malayu S.P. 2000, Manajemen Sumber Daya Manusia,: Bumi Aksara Jakarta

Handoko, T. Hani. 1995, Manajemn Personlia dan Sumber Daya Manusia. Yogyakarta: BPFE UGM.

Hidayat, 1986. Efektifitas Dalam Metode Kuantitas, Kualitas Dan Waktu, Bina Insani Jakarta

Manullang, M. 1999. Manajemen Personalia. Edisi ketujuh. Ghalia Indonesia, Jakarta.

Moleong, Lexy. J .2010. Metodologi Penelitian Kualitatif Penerbit PT. Remaja Rosdakarya, Bandung

Mangkuprawira, 2002, Manajemen Sumber Daya Manusia Strategik, Penerbit Ghalia Indonesia, Jakarta

Nawawi, Hadari, 1998, Metodologi Penelitian Bidang Sosial, Gajah Mada University Press, Yogyakarta

Nitisemito, A1ex S, 1986. Marketing, Ghalia Indonesia, Jakarta

Randall S.Schuler dan Susan E Jackson, 1999Manajemen Sumber Daya Manusia, Jilid 2, Edisi VI, Erlangga, Jakarta,

Ruky, Achmad S, 2001 Sistem Manajemen Kinerja, PT. Gramedia Pustaka Utama, PPM, Jakarta,.

Umar, Husein, 2000 Riset Sumber Daya Manusia Dalam Organisasi, PT. Gramedia Pustaka Utama, Jakarta,

Prasetyo Budi Santoso, 1984, Efektifitas Pengelolahan Kerja Input Dan Output, Pustaka Jaya Jakarta

Rachman, Maman. 1999. Strategi dan Langkah-Langkah Penelitian. Semarang: IKIP Press

Sikula, Andrew F. 2000. Manajemen SDM. Edisi Revisi, Penerbit Bumi, Jakarta

Suad Husnan, Heidjrahman. 2000. Manajemen Personalia. Edisi keempat. BPFE, Yogyakarta

Simamora, H. 1995. Manajemen Sumber Daya Manusia. Bagian Penerbitan Sekolah Tinggi dan Ekonomi YKPN, Yogyakarta,

Sondang,P, Siagian. Efektifitas Kerja, Penerbit Rafika Aditama Jakarta.

Sugiono. 2007, Metodologi Peniltian Bisnis, Bandung: ALFABETA

W.J.S. Poerwadarminta, 1985 Kamus Bahasa Indonesia, PN. Balai Pustaka Jakarta

Yeremias T. Keban, Prof. Dr. SU, MURP, 2008. Enam Dimensi Strategis Administrasi Publik, Penerbit Gaya Media 


\section{Perundang-Undangan :}

Undang Undang Nomor 43 Tahun 1999 Tentang Perubahan Atas Undang Undang Nomor 8 Tahun 1974 Tentang Pokok Pokok Kepegawaian

Undang Undang Nomor: 5 Tahun 2014 Tentang Aparatur Sipil Negara Dalam Undang Undang Nomor 22 Tahun 2004 tentang Pemerintahan Daerah

Peraturan Menteri Pendayagunaan Aparatur Negara Dan Reformasi Birokrasi (PAN dan RB) Nomor 13 Tahun 2014 Tentang Tata Cara Pengisian Jabatan Pimpinan Tinggi Secara Terbuka Di Lingkungan Instansi Pemerintah.

Peraturan Pemerintah Nomor 18 Tahun 2016 tentang Perangkat Daerah

Surat Menteri Pendayagunaan Aparatur Negara dan Reformasi Birokrasi Nomor B/3116/M.PAN/0912016 tanggal 20September 2016 